\title{
ソーシャル・キャピタルは子どもの 健康格差を緩和する鍵となるか
}

朝倉隆司

\section{学校保健学会のメインフォーラム における問題提起 ${ }^{1}$}

いわゆる Townsend らの“ブラックレポート” （1982）により健康の社会格差（あるいは社会 経済的地位による格差）が世界的に問題提起さ れてから、25年以上が経過した。この問題に 関する知見が蓄積される一方、世界経済はバブ ル景気からその崩壊、世界的大不況による混迷 へと進む過程で、格差の広がりはむしろ顕在化 し、その影響による健康格差にますます大きな 関心が集まっている。とりわけ問題は「持てる もの」と「持たざるもの」の間の健康格差であ り、社会格差は、社会経済的に低位な人々（た とえば学歴、収入、職場の地位などにおいて低 位な層）の人生に対するコントロール感を失わ せ、健康を阻害している。また、学力においても、 中位層が減少し、特に経済的に恵まれない家庭 の子どもの学力が低位にシフトし、二峰性の分 布になる傾向も指摘されている

これまで比較的社会格差が小さい“平等な国” と思われていた日本においても、近年の大きな 社会変動のなかで、経済格差の拡大が議論の的 になってきた。そして、人々が “社会的不平等” の拡大を強く意識するようになり、社会の安心・ 安全、家族内や地域などでの人々の結びつきや 信頼関係も損なわれてきた。このような社会変 動が健康格差の背景にあることは、主に大人の 健康について明らかにされてきている。
格差に伴う大人の問題は、当然ながら、子ど もたちの生活や、学習、健康に大きく影を落と している。そして、学校保健における健康格差 の問題も、単に幼児・览童生徒の健康状態に差 があることが問題なのではなく、その格差が社 会的要因あるいは社会経済格差（学歴に代表さ れる教育もその一つである）と密接に関連して 生じていることである。すなわち、子どもが州 属する家族や地域社会の社会経済的状態の良 否が、子どもの学習や心身の健康に影響すると いう問題の認識である。このような問題認識に 基づき、2009年11月に沖縄で開催された学校 保健学会のメインフォーラムにおいて、現代の 日本社会における社会経済格差が児童生徒の 健康にまで影響し、健康格差を生んでいるとの 問題提起を行ったのである。

\section{健康の社会格差問題における 要因の連鎖}

このような学校保健における健康格差の問 題は、従来の医療的アプローチや臨床的アプ ローチによる健康状態への介入により解決さ れうる問題というより、社会経済的な構造や社 会心理的要因への対応策が強く求められてい る問題なのである（図1）。“Causes of causes” という表現により、Marmotらは社会経済的な 地位の差がもたらす健康格差を明らかにして きているが、健康や学習面でのパフォーマンス 
にいたるまでの要因の連鎖において、より上流 に位置する社会的因子への介入が求められて いるのである ${ }^{3}$ これは、ヘルスプロモーショ ンの柱である「支援的社会環境の整備」「ヘル スケアの方向性の転換」、地域の「エンパワメ ント」の重要性を改めてクローズアップするこ とでもある。しかしながら、現実には、社会的 因子への社会科学的な介入よりも、これまでは 個人的な心理的因子に対する心理・教育的、あ るいは行動科学的な介入が多く行われてきた のではないだろうか。とりわけ、健康・病気に 関しては、いまだに医学的な発想のアプローチ が主流であると言わざるを得ない。そこで、社 会格差による健康格差の問題への注目が、改め てこれまでのアプローチを見直すきっかけに なることが期待される。

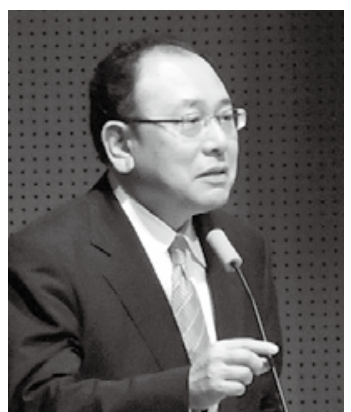

\section{PROFILE}

朝倉隆司

(あさくら たかし)

東京学芸大学教育学部教授

専門 : 健康社会学、精神保健学

\section{日本の子どもは幸福か}

さて、そもそも日本の子どもたちは、世界 の子どもたちと比べて健康で幸福なのだろう か。Unicefのレポート（2007）によると、日本 はOECD加盟 25 力国のうち「子どもの健康と 安全」では平均を下回っており、教育や文化的 なリソースの充足を調べた「子どもの物質的不 足 (material deprivation)」の比較では、世界 的に最も経済的に豊かなはずの日本がポーラ ンドに次ぎ最下位であった。逆に、「心地悪く、 居場所がない (I feel

図 1 健康を決定する因子の連鎖モデル

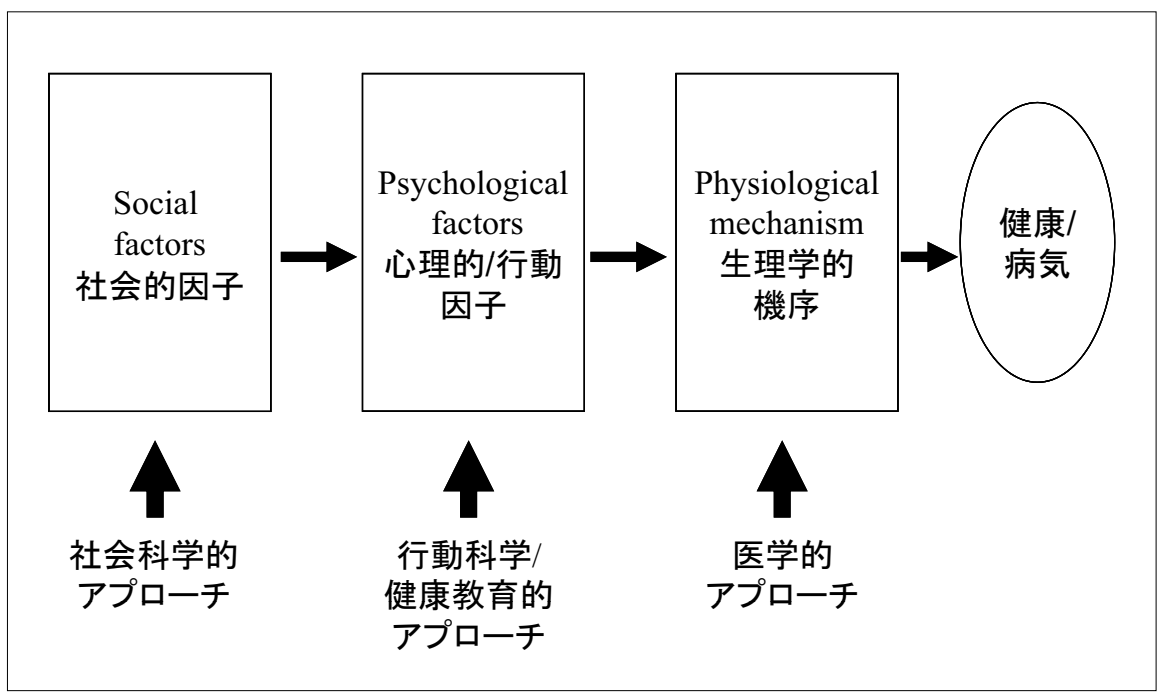
awkward and out of place.)」「孤独で、さ みしい (lonely)」と感 じている15歳の子ども は、29カ国中で突出し て高い割合である。日 本の経済発展が、子ど もたちの健康・安全と 幸福に十分に寄与して こなかったことを明確 に示している゙。ざら 
に、日本において社会経済的に恵まれない状況 におかれている子どもたちは、よりいっそう深 刻な状態にあるのではないかと危惧される。な お、これらに関しては、日本の子どもの健康や wellbeing、貧困に関して国際的に比較しうる データがそしいのも、媣刻な問題である。

われわれは日本の子どもたちの健康と幸福 のために、これまでいったい何をしてきたのだ ろうか。学校保健学会あるいはこの領域の研究 者や実践家、政策関係者に求められること、で きることは何だろうか。学校保健学会をはじめ とした子どもの健康に関連した諸学会は、健康 政策、社会政策、教育政策への提言を行ってい く必要がある。

\section{日本社会における経済格差と 子どもの健康}

さて、経済格差の拡大という社会現象は、地 域や家族における経済状態を通して、典型的に は貧困の問題によってであるが、子どもの幸福、 学習・学力、就労やキャリア、健康にも影響を 及ぼしているに違いない。これまで十分に注意 が払われてこなかった「子どもの貧困」による 問題が、やっと最近になって再びクローズアッ プされ、「子どもの貧困の再発見」と言われ、 このテーマに関する出版物も増えている。

さて、経済的な困窮という問題は、栄養・食 生活、地域資源へのアクセス、雇用、家族や保 護者のストレス等の問題、地域環境の劣化、近
隣のモラル・規範の低下などを介して、恵まれ ない社会経済的環境下の子ども達の成長と発 達に影響を及ぼすと考えられる。とりわけ、現 代の子どもたちの大きな問題である、生活習慣 の乱れ、いじめ、不登校、児童虐待、暴力、自殺、 抑うつなどの課題は、単に子ども個人の問題で はなく、彼らの背後の家庭や社会の環境と密接 な関連があり、そこへのアプローチが重要だと 考えられる ${ }^{5}$ 。

そこで経済的な困窮に対する経済政策が求 められるのだが、確かに重要ではあるが、それ によって全ての人を中流にすることは現実的 ではない。むしろ、地域環境に潜在している要 因が、子どもの健康に対しても、保護的ある いは損傷的な要因である可能性があり、子ども たちの健康や学習を促進したり、阻害したりす る可能性がある地域環境の特性が注目されて いる。たとえば、Macintyre \& Ellaway（2003） によると、地域の健康的な食べ物の值段や入手 可能性、適切な食事に対する社会的な規範や伝 統が、社会関係を通した社会的な学習や模倣 により社会化され、家庭あるいは個人内の食事 パターンや食への規範が形成される ${ }^{6}$ 。それが、 地域の住民の肥満や冠動脈疾患による死亡な どに影響するというパスウェイが考えられて いる（図2）。身近なあるいは広範な地域環境 が人々の健康に影響する社会過程を踏まえて、 このような子ども達の学習や健康に影響を及 ぼす地域社会や家庭に向けて、一体どのような 支援、対応ができるのかが、子どもの健康や学 
図2地域環境の質が健康に影響するメカニズム

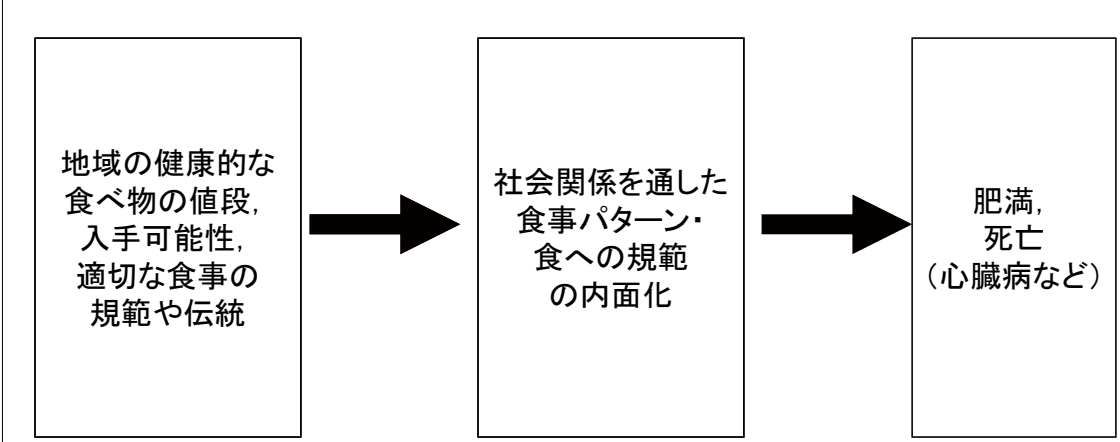

社会的な行動学習

Macintyre and Ellaway: Neighborhoods and Health: An Overview. In: Kawachi I. and Berkman LF. eds. Neighborhoods and Health. Oxford University Press. New York, pp.2042, 2003の記述をもとに、著者が図を作成した。

童や青少年などの年齢 層にも普遍化できるの か、検討が必要である。

現在、特定の社会集 団のメンバーが利用可 能なリソース（資源） としてのソーシャル・ キャピタルという考え 方と、個人と集団の ネットワークに埋め込 まれたリソースとして 捉える考え方がある。

習に社会的責任を負う専門家に対して問われ ているのである。

\section{社会格差の健康影響と ソーシャル・キャピタル}

最近、貧困の健康影響に対して、その影響を 緩和する可能性がある、地域や集団あるいは個 人の特性としてソーシャル・キャピタルという 概念が注目されてきた。それは、経済的な格差 に対して保護的に働くというだけではなく、子 どもの健康の予測因子でもあるからである。と ころが、ソーシャル・キャピタルの概念的な定 義は、専門家の間でいまだにコンセンサスが得 られていない。しかも、ソーシャル・キャピ夕 ルは、アメリカ社会における概念であり、大人 のデー夕を中心に検討されてきたために、他の 社会文化に属する人々やエスニック集団、児
たとえば、ブルデューは個人レベルで社会的に 構成されたソーシャル・キャピタルを考えてお り、パットナムは集団・地域レベルのエコロジ カルで文脈的なソーシャル・キャピタルを考え ている。このような理論的な違いが混乱をもた らしている。

おおまかにいって、信頼、互恵的サポート、 互酬性の規範、インフォーマルな規範や統制、 自発的な社会活動などの要素がソーシャル． キャピタルを構成すると考えられている。個人 レベルで考えるソーシャル・キャピタルは、共 有される信頼、規範、価值、互恵的関係や規範 といった集団内のメンバーがアクセス可能な 潜在的リソースであり、ブルデューによると、 メンバーによって過去に互いに投資を行った 経験に基づいて社会化され、個人内にリソース として蓄積されたものと考えられる。 


\section{地域の環境特性とソーシャル・ キャピタルの健康影響}

そのようなソーシャル・キャピタルが健康に 影響するメカニズムとして、いくつかの仮説が 考えられている。たとえば、人間関係のネット ワークに存在する、互恵的関係性やサポート、 信頼、規範、価值、情報といったリソースを使っ て、健康増進、疾病の予防、病気の改善などが 促進されるのではないか。そのネットワークを 通じて雇用など経済的な条件が改善、促進され、 生活状態が良くなることで、健康に好ましい影 響がもたらされるのではないか。ソーシャル・ キャピタルにより、貧困を軽減するようなスキ ルの開発や習得が行われ、生活水準が向上する ことで、健康に好ましい影響がもたらされるか
もしれない。日々のライフイベントによりもた らされる心理社会的ストレスを、ソーシャル・ キャピタルにより軽減することができ、精神的 な安寧を増すのではないか、などである7。

著者は、中学生を対象に、このような一般的 信頼感、近隣、家族、教員への信頼感の 4 項目 に加え、友人間でのサポートの授受（互恵的関 係性やサポート)、ルールや約束事の遵守とい う共通の規範からなるソーシャル・キャピタル を個人レベルで測定する尺度を作成した。また、 「利便性と設備・サービスの充実」「近隣の人間 関係の結束」「臱いやスポーツの場 (スペース)」 「治安の悪さ、事故の危険性」「密集・猥雑、非 衛生」「自発的地域活動」「街の美観と静烅」か ら近隣の地域環境の質を捉える尺度を開発し たのである 8 。そして、性、家族背景、居住年 図３＼cjkstart地域環境の質、個人レベルのソーシャルキャピタルと精神健康の関連

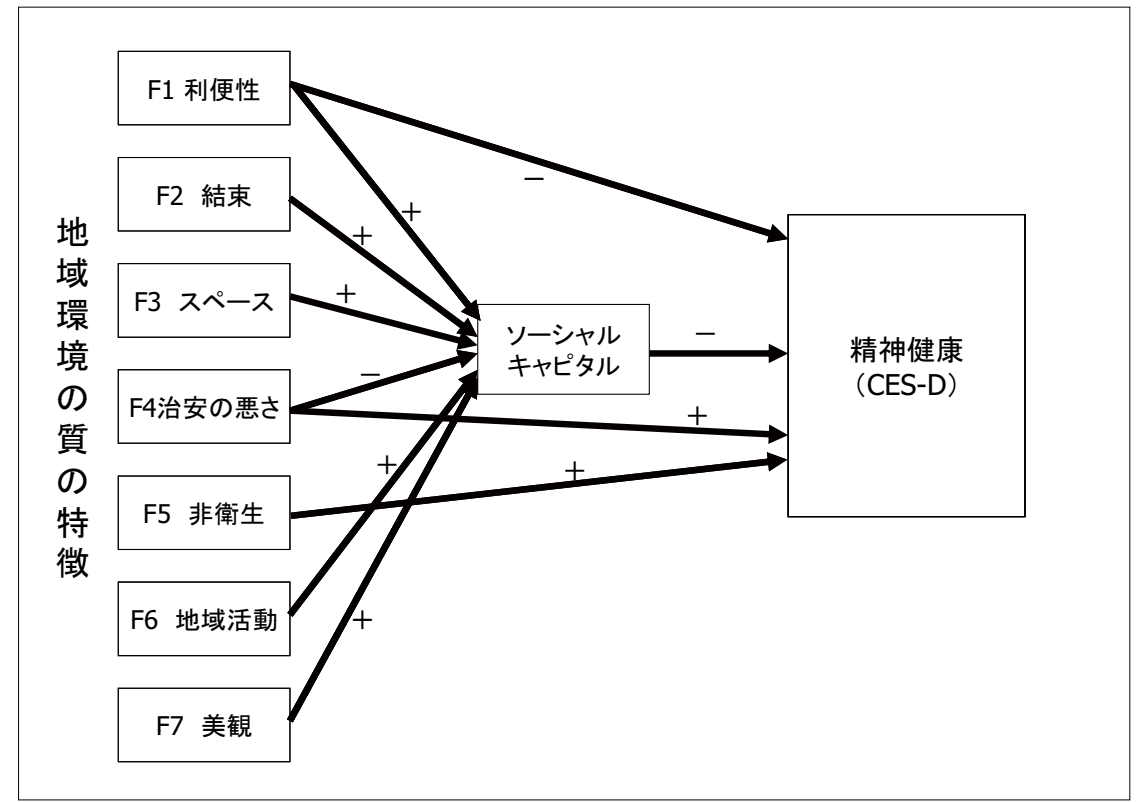

数、居住都市、学校内相 関を統制して、地域環境 の質が個人レベルのソー シャル・キャピタルを介 して精神健康に及ぼす影 響を重回帰分析によって 検討した。その結果を模 式的に表したのが図3で ある。「密集・猥雑、非 衛生」を除いた全ての尺 度は、個人レベルのソー シャル・キャピタルに影 響していた。そして、個 人レベルのソーシャル . 
キャピタルと精神健康の指標である抑うつ度 とは、有意な関連があることが明らかになった。 さらに、「利便性と設備・サービスの充実」「治 安の悪さ、事故の危険性」「密集·猥雑、非衛生」 は、直接的にも精神健康と関連があることが示 された。身体的健康、学業成績の評価を、精神 健康に代わって影響を受ける現象と想定した 場合も、地域環境の質や個人レベルのソーシャ ル・キャピタルとの関連は、ほぼ同様であるこ とがわかってきたのである。地域の環境の質 が、子どもの心身の健康や学習において、一定 の影響を及ぼしている可能性があること、そし て個人レベルのソーシャル・キャピタルは、両 者の関係を調整する要因である可能性がある。 すなわち、地域の抱える問題を改善することが、 直接、間接に子どもの健康や学習の向上に結び つくことを示唆している。

さらに注目すべき点は、地域環境の質の劣化 は、二重の不利をもたらす可能性があることで ある。すなわち、地域環境が質的に不良好であ ることは、様々な教育や保健医療に関する地域 資源へのアクセスが限られるなどから、直接的 に健康や学習を阻害する可能性がある。同時に、 個人レベルのソーシャル・キャピタルという健 康や学習を推進する資本の蓄積そのものを低 下させる可能性がある。

\section{地域の特性が学習・健康に 至るまでのパスウェイ}

このモデルをもとに、地域の社会経済状態、 すなわち社会経済格差の影響が、地域の質的 な環境特性、個人レベルのソーシャル・キャ ピタルを介して、学習・健康に至るまでのパ スウェイを考えてみた。そ

図4 社会経済状態の影響が、地域の質的な環境特性、個人レベルのソー シャル・キャピタル、学習・健康に至るまでに想定されるパスウェイ

\begin{tabular}{|c|c|c|c|}
\hline \\
\hline $\begin{array}{l}\text { 曰 } \\
\text { 高学歴で、経 } \\
\text { 済的に豊かな } \\
\text { 人たちが多い } \\
\text { 地域では } \\
\text { (composition) }\end{array}$ & $\begin{array}{l}\text { 人々は親 } \\
\text { 切で互い } \\
\text { に挨拶し、 } \\
\text { 街は美しく、 } \\
\text { 治安が良く } \\
\text { て、利便性 }\end{array}$ & $\begin{array}{l}\text { 子ども達は、地 } \\
\text { 域の人から人 } \\
\text { を信頼し、助け } \\
\text { 合う気持ちを } \\
\text { 学び、社会規 } \\
\text { 範を身につけ } \\
\text { て生活しており }\end{array}$ & $\begin{array}{l}\text { 学業も良好 } \\
\text { で、心身も } \\
\text { 健康である } \\
\text { （health/ } \\
\text { wellbeing） }\end{array}$ \\
\hline $\begin{array}{l}\text { 経済的援助。し } \\
\text { かし、全ての人を } \\
\text { 経済的な中流に } \\
\text { はできない }\end{array}$ & $\begin{array}{l}\text { Health promotionの } \\
\text { 支援的環境づくり }\end{array}$ & $\begin{array}{l}\text { (social capital） } \\
\text { 家庭、学校はこの部 } \\
\text { 分を道德教育、心理 } \\
\text { 教育などでなんとか } \\
\text { しようとしている }\end{array}$ & $\begin{array}{l}1 \\
\text { これまで保健 } \\
\text { 医療、健康 } \\
\text { 教育はここに } \\
\text { アプロ一チし } \\
\text { てきた }\end{array}$ \\
\hline
\end{tabular}

れが図4である。ちなみ に、地域の特性のうち、 人の構成に関わる特性が compositional 要因であ り、そのような人々が生活 して創出する質的特性が contextual な要因である。

現在著者が考えている要 因連鎖の仮説では、高学歴 で経済的に豊かな人たちが 多い地域では、人々は親切 で互いに挨拶し、街は美し 
く衛生的に保たれ、治安が良くて、利便性や公 共の設備・サービスも良好であり、そこで生活 する子ども達は、地域の人から人を信頼し、助 け合う気持ちを学び、社会規範を身につけて生 活するよう社会化されるだろう。とりわけ地域 の人々の信頼、連带や協力、社会参加といった 地域レベルのソーシャル・キャピタルから影響 を受けて、個人レベルでのソーシャル・キャピ タルも創出され、蓄積されるであろう。そのよ うな社会関係から得た無形の資本を豊かに蓄 えた子どもたちは、学業も良好で、心身も健康 に発達するのではないか、という仮説である。

ここで、社会政策を考えるとしたら、政策 により、現在の多様な地域に住む人々の多く を、高学歴で経済的に豊かな人たちに変えるこ とは、現実的には不可能である。しかし、地域 の人々の連帯や結束を強め、フォーマル、イン フォーマルな地域活動によって、街を美しく衛 生的に保ち、地域の秩序や治安を守ること、公 共交通や公共の設備・サービスへのアクセシビ リティを高めることは可能ではないだろうか。 このような公共施策により、子どもの健康や学 習を改善することができるとすれば、心理・教 育的アプローチよりも効果が上がることが期 待されるのではないだろうか。

仮に、地域社会や国における行動規範が、非 常に個人主義的であったらどのようなことが 起こるだろうか。たとえ雇用や経済政策により 人々の経済的な生活水準が改善したとしても、 その豊かさは人々の連帯や協力による支援的
な地域社会の環境づくりには向かわず、直接個 人やその家族を利する学習・教育や健康への投 資に繋がり、必ずしも社会には還元されないか もしれない。そうだとすれば、個人主義的志向 性が強い社会における経済政策は、より格差を 拡大してしまう可能性があることが懸念され る。したがって、国や自治体が貧困対策として 経済政策を行うにしても、同時に地域環境の質 の改善に向けた介入も行うべきだと提言する ことができよう。

\section{ソーシャル・キャピタルの負の側面}

当然のことだが、ソーシャル・キャピタル を、国や自治体が当然行うべき貧困や経済格差 を解消するための対策の「安価な代替策」とみ なしてはならない。また、問題解決を地域の自 己責任として押しつけてもならない。ソーシャ ル・キャピタルを構築する魔法のような方法は 存在せず、行政施策による地域への投資と地域 の活性化を図る住民主体の取り組みの両輪に より、地道に行われるべきである ${ }^{9}$ 。その際には、 ソーシャル・キャピタルの負の側面にも、十分 な配慮が必要である ${ }^{10}$ 。それは以下の 4 点にま とめられている。すなわち、(1)凝集性の高い集 団のメンバーから、他者に対してサポートを提 供するようにという過度の要求がされる可能 性がある。(2)個人の自由を制限しかねないほど 規範に従うことが期待されがちである。(3)集団 内の結束のために、集団外の人を排除する傾向 
が生じかねない。(4)社会的な出世の見込みを妨 げてでも、メンバーを平均化してしまう規範が 強まる可能性がある。

\section{今後の学術的課題}

理論や方法論的な困難さ故でもあるが、日本 ではまだ地域環境の質や物質的並びに経済的 な地域の特性、ソーシャル・キャピタルを測定 し、子どもの健康や学習との関連を実証的に検 討した研究がそしい。したがって、そのメカニ ズムについても、ほとんど未知である。成人や 高齢者を対象にした研究はいくつか行われて いるが、児童期や思春期を対象にした研究がと りわけそしい。この領域の学術的な発展が望ま れる。また、高橋が指摘したように、学校保健 の専門家としては、健康に寄与する学力のあり 方を探索する研究も、学術的に重要な課題とい えよう ${ }^{2}$

註

1 朝倉隆司、高橋浩之：社会格差の広がりと子どもの健 康への影響一今、学校保健に何が求められているか一 フォーラム企画者からの問題提起、学校保健研究、51 Suppl.:60-61、2009

2 高橋浩之：子どもの教育と健康における格差、学校保健 研究、51 Suppl.:68-69、2009

3 Marmot M: The Status Syndrome: How Social Standing Affects Our Health And Longevity. Owl Books, New York, 2005

4 Child poverty in perspective: An overview of child well-being in rich countries. http://www.unicef-irc.org/ publications/pdf/rc7_eng.pdf

5 浅井春夫、松本伊智朗、湯澤直美編: 子どもの貧困、 287、明石書店、東京、2008

6 Macintyre S and Ellaway A: Neighborhoods and Health: An Overview. In : Kawachi I. and Berkman LF. eds. Neighborhoods and Health. Oxford University Press. New York, pp.20-42. 2003.

7 Waterston T, Alperstein G, Brown SS: Social capital: a key factor in child health inequalities. Arch Dis Child 2004; 89:456-459

8 朝倉隆司：ソーシャルキャピタルと子どもの健康の社会 格差、学校保健研究、51 Suppl.:70-71, 2009

9 I. カワチ、S.V. スブラマニアン、D. キム:ソーシャル・キャ ピタルと健康 これまでの10年間と今後の方向性、イチ ロー・カワチ、S.V.スブラマニアン、ダニエル・キム編 (藤澤由和、高尾総司、濱野強監訳)、ソーシャル・キャ ピタルと健康、9-48、日本評論社、東京、2008

10 Portes A : Social Capital: Its Origins and Applications in Modern Sociology. Annu Rev Sociol 24: 1-24, 1998 